\title{
Dijital Görüntüler Kullanılarak Kan Grubunun Görüntü İşleme Tabanlı Tespiti
}

\author{
Hilal Atıc1 ${ }^{*}$, Hasan Erdinç Koçer², Saadet Kader $^{3}$
}

Geliş / Received: 14/11/2019

Revize / Revised: 02/07/2020

Kabul / Accepted: 08/07/2020

ÖZ

Kan gruplandırılması, temel tıbbi prosedürlerin çoğu için ilk ve en önemli gerekliliktir. Kan grubunu tespit etmede kullanılan geleneksel teknikte uzman, kan örneğine anti-serum madde karıştırarak kandaki renk ve biçim değişikliğini izler ve kan grubu ile Rh faktörünü belirler. Bu işlem uzman tarafından gün boyunca yapılmaktadır ve yorgunluk, gözden kaçırma gibi sebeplerden dolayı hataya açıktır. Bu çalışmada, görüntü işleme teknikleri kullanılarak kan grubunun otomatik olarak tespit edilmesi amaçlanmıştır. Bunun için gerçek hasta kanlarının dijital görüntüleri üzerinde bir dizi görüntü işleme tekniği uygulanmıştır. Alınan kan görüntüleri üç bölüme ayrıldıktan sonra öncelikle RGB-Gri seviye-Siyah/Beyaz dönüşümü yapılmıştır. Ardından morfolojik işlemler uygulanarak kan bölgesi segmente edilmiş ve kenar sınır çizgileri işaretlenmiştir. Son aşamada ise beyaz piksel yoğunluğu, bölge içerisindeki nesne sayısı ve kenar piksel sayısı tespit edilerek kan grubu ve Rh faktörü belirlenmiştir.

Anahtar Kelimeler- Kan Grubu Tespiti, Görüntü İşleme, Segmentasyon, Sınıflandırma

1*Sorumlu yazar iletişim: hilalatici@eskisehir.edu.tr (https://orcid.org/0000-0002-1859-8085)

Bilgisayar Mühendisliği, Selçuk Üniversitesi, Konya, Türkiye

2̇letișim: ekocer@selcuk.edu.tr (https://orcid.org/0000-0002-0799-2140)

Elektrik Elektronik Mühendisliği, Selçuk Üniversitesi, Konya, Türkiye

3lletişim: saadetkader@hotmail.com (https://orcid.org/0000-0003-0646-946X)

Karapınar Devlet Hastanesi, Konya, Türkiye 


\title{
Determination of Blood Group by Image Processing Using Digital Images
}

\begin{abstract}
Blood grouping is the first and most important requirement for most basic medical procedures. The expert in the conventional art used to detect blood type monitors the color and shape change in the blood by mixing anti-serum substance into the blood sample and determines the blood group and $\mathrm{Rh}$ factor. This is done by the expert throughout the day and is open to errors due to tiredness and oversight. In this study, it was aimed to determine blood group automatically by using image processing techniques. For this purpose, a series of image processing techniques have been applied on digital images of real patient blood. After the blood samples were divided into three parts, firstly RGB-Gray level-Black/White conversion was performed. Subsequently, morphological procedures were performed, and the blood region was segmented and border lines were marked. In the last stage, the white pixel density, the number of objects in the region, and the number of edge pixels were determined and blood group and $\mathrm{Rh}$ factor were determined.
\end{abstract}




\section{INTRODUCTION}

Blood is one of the most important elements of the human body, which acts as the main connective tissue and holds the circulation of many essential components, such as oxygen and various nutrients.

The traditional method of detecting blood type is usually plate test and tube test [5]. Both are performed under complete analog procedures with human observation. It is insufficient to perform the most basic and necessary medical procedure in a completely analogous environment. There are also several techniques, such as microplate testing and gel centrifugation [5,7]. These procedures are expensive and need to be performed by people with strong skills and some special equipment.

With the developing technology, the use of modern devices in healthcare has increased. Therefore, the use of image processing techniques in medicine has become widespread. These techniques provide great convenience to physicians in terms of time, cost, treatment, and diagnosis.

Basically, the process of blood group analysis depends on the deposition of a sample of blood. The blood of a patient is mixed with three types of antigen; antigen A, antigen B, and antigen D. Agglutination in any blood sample ensures the positivity of the blood belonging to the group of interest.

Agglutination can also be detected by human eyes, but errors in these procedures may occur. Incorrectly detected blood type may cause incorrect medical procedures. For this reason, it is important that the blood type determination be determined perfectly $[4,6]$.

Image segmentation is one of the basic techniques of image processing. In segmentation, a large image is divided into several sub-images. When the algorithms are run separately on the images in the subsections, the calculations are more pronounced and the result becomes more precise.

Another important image processing technique is the thresholding method. The threshold divides any image into two basic parts. In some cases, segmented images may become blurred, and important information that may need to be extracted may not be extracted. Thresholding is very useful in such cases [2].

In this study, a blood group determination system was proposed which gave a definite result in a short time. The traditional medical laboratory procedure concludes by looking at a reaction output consisting of the following steps:

- Blood samples are placed on a white surface,

- Anti- serums are dripped onto blood samples,

- Blood samples and anti-serums are mixed,

- Wait until the reaction is carried out,

- The blood type is determined by looking at the output.

This process takes time and needs an expert to perform this operation. Therefore, it is important to realize an expert system.

In a study, the blood group was determined by applying image processing techniques on the digital image taken with the serum dripped onto the blood. Firstly, the images were converted to gray level and then converted to binary format. After this image was divided into three parts, each one was applied a Canny edge detection algorithm. With the tests, the threshold value was determined as 32, and it was determined whether there was $a$ sedimentation in the blood according to this value. The blood group was determined using the latest classification algorithm [6]. In this study, the blood group was classified according to three parameters. These parameters are; the number of edges, the number of white pixels and the total number of elements in each segmented image.

In 2016, a study was conducted on blood group detection; white blood cell (WBC) and red blood cell (RBC) number determination. In this study, digital blood images were used for blood group detection and microscopic blood images were used for WBC and RBC counting. Image processing techniques, such as 
segmentation, morphological processes, and Circular Hough Transform were used in the study. The system achieved an average of $90 \%$ accuracy rate [11].

In another study, digital blood images were first converted from RGB format to HSV format and then to binary format. Morphological procedures were applied to clear noisy data on the binary image. Histogram information of the images was extracted. The images are divided into three parts according to histogram information. Feature extraction was applied to these parts. Parts were classified according to white pixel density and number of objects [1].

In a study, a method based on the processing of images obtained during blood group detection was developed. Image processing techniques, such as threshold and morphological processes are used. The developed automatic method determines the blood group using image processing techniques. The methods and advantages of human blood group determination using SIFT transformation, and SVM classifier are discussed [8].

In 2018, a study was conducted on the correct and rapid identification of the blood group based on image processing technology. First, image processing technique, such as the HSV brightness plane was used to detect the background color. Then morphological operations were done on the images. In this method, clusters are classified to identify the blood group by determining the area of a cluster. The method was able to classify the blood group quickly and accurately [9].

In a study conducted in 2018, an automatic system that determines the blood group using image processing techniques was developed. Using LABVIEW and IMAQ vision, the blood group is identified. The blood sample and the antigen are mixed and then the image of the mixture is captured. Based on the occurrence of agglutination reaction, the blood group of the patient is identified. The mixing of antigen and the blood samples is done manually, so this system is not fully automated [10].

In this study, a study was performed on a patient dataset collected from Karapınar State Hospital Laboratory. The data set was received via a camera with a resolution of $12 \mathrm{MP}$. The images obtained have a resolution of $1500 \times 400$. The data set consists of a total of 52 images obtained from previously tested blood samples, and the blood group of these images is already known. In this data set, at least three and at most five images were taken from each type of blood group.

\section{MATERIALS AND METHODS}

In this study, automatic blood group detection by using image processing techniques with laboratory technician to blood group detection technique is discussed. What the technician needs to do is to put the blood on the white plate and mix it properly with the anti-serum and finally take an image.

The image taken from the environment where the objects are located is first converted to gray level and then converted to binary format. Morphological procedures are applied to eliminate the noise on the image. After prewitt edge detection algorithm was applied to the image, segmentation was performed with BoundingBox. After the feature extraction operations were applied to the separated image, classification was applied according to these properties.

The main steps in this application will be as follows;

1. Image Capture

2. Image Preprocessing and Segmentation

3. Determination of Blood Type 


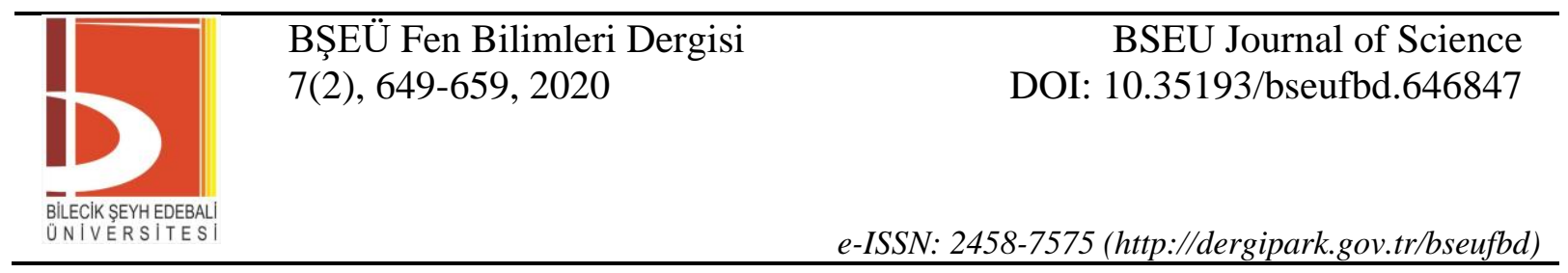

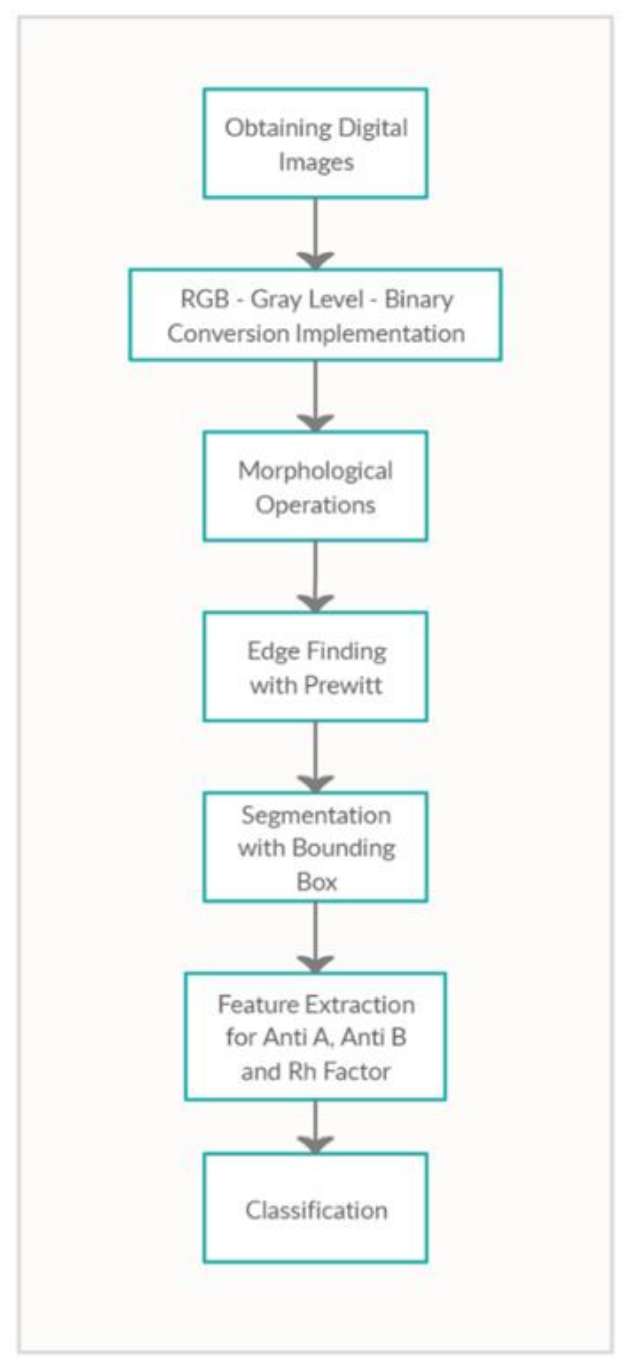

Figure 1. Stages of the proposed system

\section{A. Image Acquisition}

Images of the test slides were taken using a digital camera as shown in Figure 2. Plates contain blood sample mixed with anti-serums. Images were used in the application for further processing.

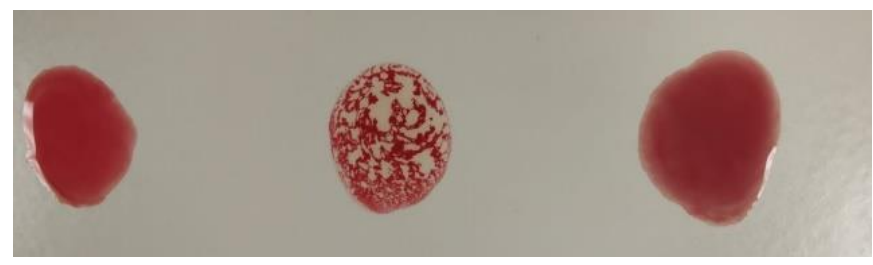

Figure 2. Anti-serum blood image obtained in the laboratory 


\section{B. Preprocessing}

The preprocessing step involves resizing the image to a specific format. It involves converting the image from RGB to gray scale, converting the gray scale to binary image, and then segmenting the processed image for post-processing using advanced morphological procedures.

1) Gray Scale Conversion: In general, the grayscale image shows the image in which each of its pixels represents a certain amount of light range. The grayed-out image of Figure 2 is shown in Figure 3.

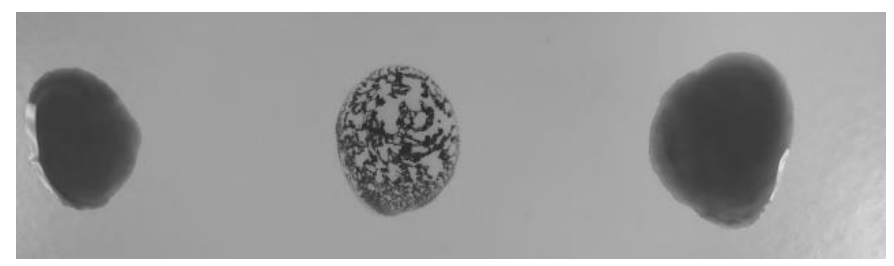

Figure 3. Converting image to gray level

The process of converting a color numeric image into a gray-toned image is actually the scaling of the gray-toned images that correspond to each color band specified in the RGB color model. In this sense, the scaling process performed by sticking to the brightness values of the color image;

$$
\text { Gray Value }=0.299 x R+0.587 x G+0.114 x B
$$

it is expressed with. With the equation (1), the gray-tone equivalent of the color image is obtained. (Figure 4).

2) Binary Transformation: The image was converted to a binary format after being converted to gray level

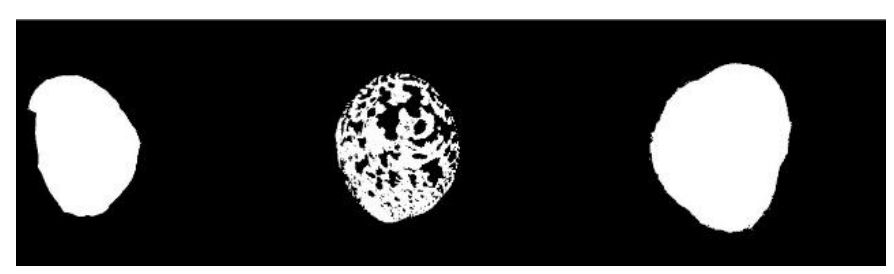

Figure 4. Converting an image to binary format

In the binary transformation stage, the color value of each pixel in the image is compared with a certain threshold value. If this is below the threshold value, one color is assigned, and if above, another color is assigned. When passing a grayscale image through this filter, it is assigned 0-black if the color value is equal to or below a threshold value of 128, and 1-white if the threshold is above the value. This process can be shown mathematically as follows;

$$
f(x, y)=\left\{\begin{array}{rr}
0 & \text { if } g(x, y)<T=128 \\
1 & \text { other }
\end{array}\right.
$$

3) Morphological Operations: Some basic morphological procedures were performed on the binary image to correct any defects and to better manipulate the image. At this stage, small particles, noise, unwanted situations on the image were deleted. Morphological process on the same image first dilation followed by erosion. Dilation is a morphological process used to magnify or emphasize objects in binary images. Dilation process;

$$
A \oplus B=\bigcup_{b \in B} A_{b}
$$




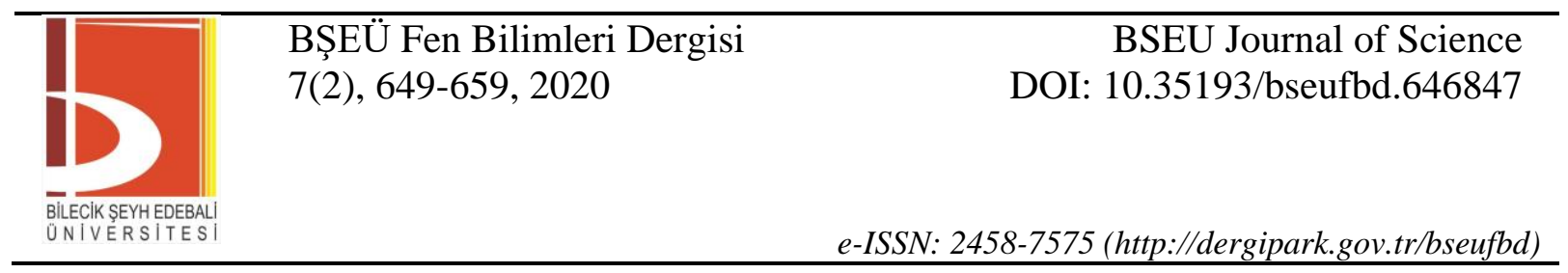

it is expressed by the formula.

In the erosion process, the pixels within the area specified according to the parameters are abraded, and the distorted image, called noisy, is cleaned from noise. Erosion process;

$A \ominus B=\bigcap_{b \in B} A_{-b}$

it is expressed by the formula.

4) Segmentation: Segmentation is the process of dividing a digital image into multiple segments within pixel sets. Dilate operation on the image filled the gaps in the image. Then clear particles filled with voids were obtained (Figure 5.).

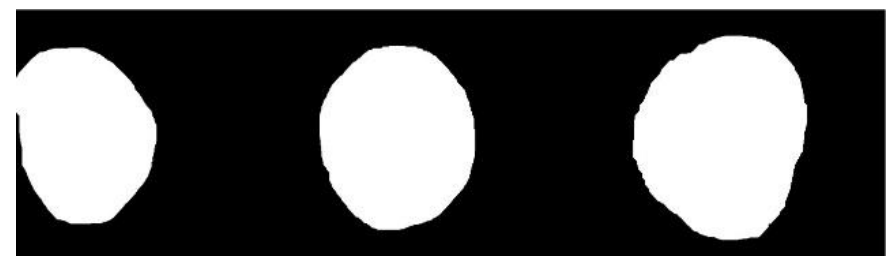

Figure 5. Filling the gaps in the image by dilation

After filling the gaps in the image, the edges in the image were determined by prewitt edge finding method. Boxes surrounding objects in the drawn image were detected.

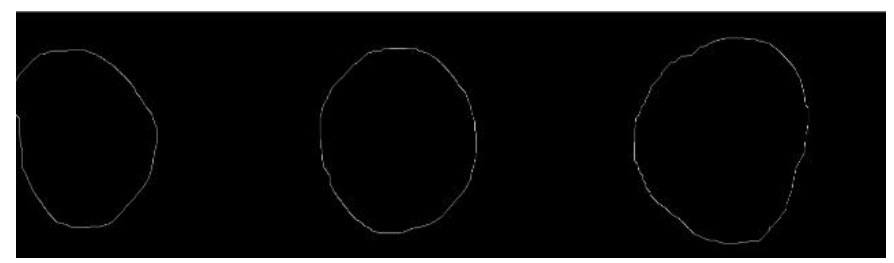

Figure 6. Finding the edges of the image

Zoning function was used to divide the image with edges.

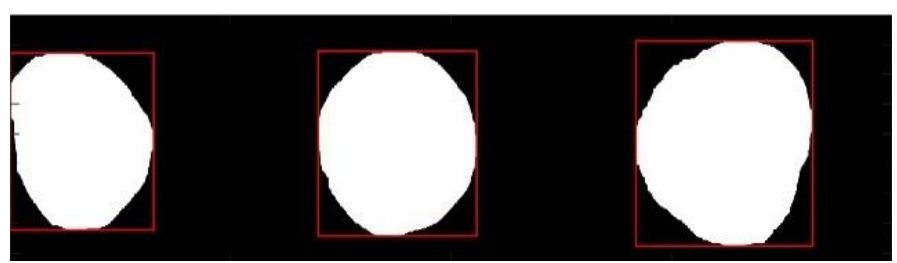

Figure 7. Bounding Box

The largest frames were used for segmentation. 


\begin{tabular}{|c|c|c|}
\hline & $\begin{array}{l}\text { BŞEÜ Fen Bilimleri Dergisi } \\
7(2), 649-659,2020\end{array}$ & $\begin{array}{r}\text { BSEU Journal of Science } \\
\text { DOI: } 10.35193 / \text { bseufbd. } 646847\end{array}$ \\
\hline 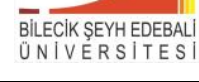 & & 88-7575 (http://dergipark.gov.tr/bseufbd) \\
\hline
\end{tabular}

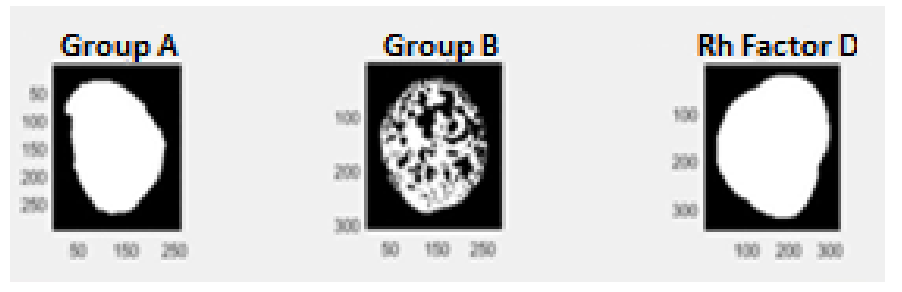

Figure 8. (a) Group A, (b) Group B, (c) Rh Factor group segmentation of blood image

\section{Blood Group Determination}

The blood group is determined using three features from the segmented image indicated below;

- The intensity of the white pixels of each segmented region (the area of the area consisting of white pixels) is calculated in the first place,

- And then calculated the total number of objects (elements) in each partitioned image,

- The number of edges in each last split image is determined.

These three characteristics clearly define that the distorted blood region has fewer white pixels (meaning less red components), more elements in the image, and more edges.

Using these features, distorted portions of the segmented images are easily detected. Figure 9 shows the original image and segmented version.

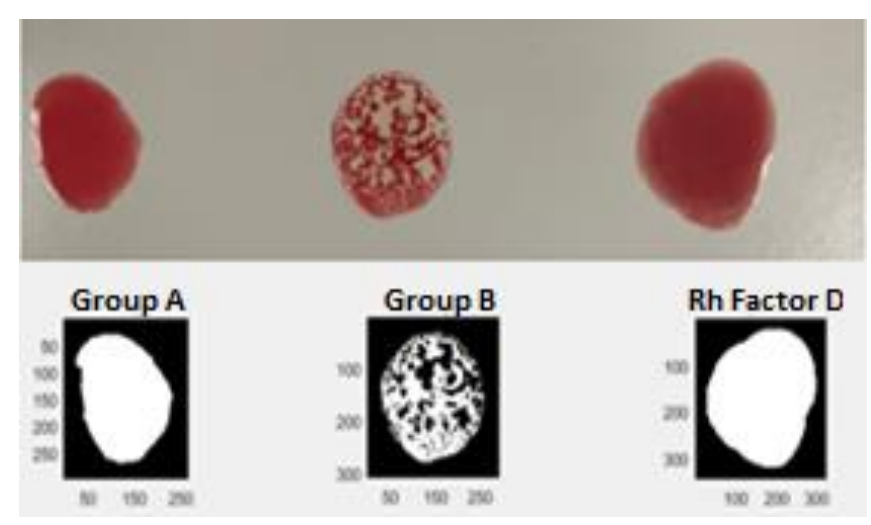

Figure 9. Original and segmented image of type B Positive Blood Group

In Figure 10, the Prewitt edge detection technique was applied to each of the partitioned binary images. When this technique is applied, the number of edges formed is used in the classification process.

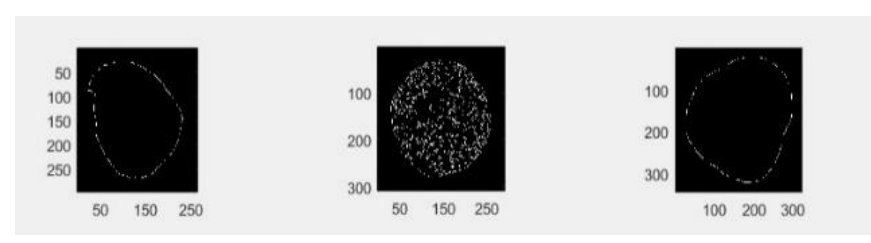

Figure 10. Application of Prewitt edge detection technique to blood image in (a) Group A, (b) Group B, (c) Rh Factor group 


\begin{tabular}{|c|c|c|}
\hline & $\begin{array}{l}\text { BŞEÜ Fen Bilimleri Dergisi } \\
7(2), 649-659,2020\end{array}$ & $\begin{array}{r}\text { BSEU Journal of Science } \\
\text { DOI: } 10.35193 / \text { bseufbd. } 646847\end{array}$ \\
\hline $\begin{array}{l}\text { BiLECCKS SEYH EDEBALL } \\
\text { ONIVERSITESI }\end{array}$ & & 88-7575 (http://dergipark.gov.tr/bseufbd) \\
\hline
\end{tabular}

Table I shows the white pixel density (number of white pixels), number of objects (Red blood cell regions), and number of edges in each of the above segmented sections of images. Here it refers to those shown as dark regions without disruption.

By careful examination, a threshold can be determined on these three properties to help identify the region with or without distortion. As a result of the experiments, the threshold value for white pixel density is 20000 , the threshold value for the number of objects is 5 , and the threshold value for the number of edges is 32 .

Table 1. White pixel density in image - number of objects - number of edge

\begin{tabular}{|c|c|c|c|c|c|c|c|c|c|}
\hline & Bölge & $A+$ & $A-$ & $B+$ & $B-$ & $A B+$ & $A B-$ & $0+$ & 0 \\
\hline \multirow{3}{*}{$\begin{array}{c}\text { White } \\
\text { Pixel } \\
\text { Density }\end{array}$} & I & 10766 & 18671 & 32041 & 46828 & 27650 & 27647 & 35541 & 33170 \\
\hline & II & 20201 & 30759 & 6069 & 19282 & 17190 & 17193 & 30758 & 33717 \\
\hline & III & 12916 & 34873 & 8816 & 34712 & 5789 & 32973 & 6724 & 42558 \\
\hline \multirow{3}{*}{$\begin{array}{c}\text { Number of } \\
\text { Object }\end{array}$} & I & 22 & 29 & 1 & 1 & 10 & 10 & 2 & 2 \\
\hline & II & 11 & 7 & 53 & 9 & 24 & 24 & 7 & 1 \\
\hline & III & 5 & 1 & 7 & 1 & 17 & 1 & 15 & 1 \\
\hline \multirow{3}{*}{$\begin{array}{c}\text { Number of } \\
\text { Edge }\end{array}$} & I & 47 & 202 & 1 & 1 & 237 & 235 & 14 & 5 \\
\hline & II & 20 & 25 & 65 & 67 & 171 & 173 & 26 & 1 \\
\hline & III & 9 & 1 & 8 & 1 & 17 & 1 & 15 & 21 \\
\hline
\end{tabular}

That is, if a region has more than 20000 white pixels, fewer than 5 objects, and less than 32 edges, that region is perceived as intact region. Otherwise, if a region has less than 20000 white pixels, more than 5 objects, and more than 32 edges, it will be detected as a degraded region.

Table 2 shows the deterioration conditions used to determine blood group in the classification. If the deterioration occurs as a result of serum dropped into the blood, there is a deterioration, otherwise it can be expressed as no deterioration. The tick $(\checkmark)$ sign is distortion, and the cross $(X)$ sign indicates no distortion. For example, the presence of degradation for all three antigens indicates $\mathrm{AB}+$, the absence of degradation for all three antigens indicates that the 0-blood group.

Table 2. Blood group determination criteria

\begin{tabular}{cccc}
\hline & Anti A & Anti B & Anti D \\
\hline $\boldsymbol{A +}$ & $\checkmark$ & $\mathrm{X}$ & $\checkmark$ \\
\hline $\boldsymbol{A}-$ & $\checkmark$ & $\mathrm{X}$ & $\mathrm{X}$ \\
\hline $\boldsymbol{B}+$ & $\mathrm{X}$ & $\checkmark$ & $\checkmark$ \\
\hline $\boldsymbol{B}-$ & $\mathrm{X}$ & $\checkmark$ & $\mathrm{X}$ \\
\hline $\boldsymbol{A B}+$ & $\checkmark$ & $\checkmark$ & $\checkmark$ \\
\hline $\boldsymbol{A B}-$ & $\checkmark$ & $\checkmark$ & $\mathrm{X}$ \\
\hline $\boldsymbol{0}+$ & $\mathrm{X}$ & $\mathrm{X}$ & $\checkmark$ \\
\hline $\boldsymbol{0 -}$ & $\mathrm{X}$ & $\mathrm{X}$ & $\mathrm{X}$ \\
\hline
\end{tabular}




\begin{tabular}{|c|c|c|}
\hline & $\begin{array}{l}\text { BŞEÜ Fen Bilimleri Dergisi } \\
7(2), 649-659,2020\end{array}$ & $\begin{array}{r}\text { BSEU Journal of Science } \\
\text { DOI: } 10.35193 / \text { bseufbd. } 646847\end{array}$ \\
\hline & & 88-7575 (http://dergipark.gov.tr/bseufbd) \\
\hline
\end{tabular}

\section{RESULTS AND DISCUSSION}

Evaluation of the proposed system was performed on the patient data set collected from Karapınar State Hospital Laboratory. The data set was taken using a simple digital camera.

The data set consists of a total of 52 images from previously manually tested blood samples, and the blood type of these images is already known. In this dataset, at least three to five images of each blood group type were taken. After processing 52 images in our database, the results were compared with the results determined by the expert. Accordingly, 44 of 52 images were classified as correct blood group and $84.615 \%$ success rate was obtained. Confusion Matrix showing the correct detection rates of application results according to blood groups is given in Table 3.

Table 3. Confusion matrix

\begin{tabular}{ccccccccc}
\hline & $\boldsymbol{A +}$ & $\boldsymbol{A}-$ & $\boldsymbol{B}+$ & $\boldsymbol{B}-$ & $\boldsymbol{A B}+$ & $\boldsymbol{A B}-$ & $\boldsymbol{0 +}$ & $\boldsymbol{0}-$ \\
\hline $\mathbf{A +}$ & $\mathbf{6}$ & $\mathbf{1}$ & 0 & 0 & 0 & 0 & 0 & 0 \\
\hline $\mathbf{A -}$ & 0 & $\mathbf{5}$ & 0 & 0 & 0 & $\mathbf{1}$ & 0 & 0 \\
\hline $\mathbf{B}+$ & 0 & 0 & $\mathbf{4}$ & $\mathbf{1}$ & 0 & 0 & 0 & 0 \\
\hline $\mathbf{B}-$ & 0 & 0 & 0 & $\mathbf{6}$ & 0 & 0 & 0 & 0 \\
\hline $\mathbf{A B}+$ & 0 & 0 & 0 & 0 & $\mathbf{4}$ & $\mathbf{1}$ & 0 & 0 \\
\hline $\mathbf{A B}-$ & 0 & 0 & 0 & 0 & 0 & $\mathbf{6}$ & 0 & 0 \\
\hline $\mathbf{0 +}$ & 0 & 0 & 0 & 0 & 0 & 0 & $\mathbf{6}$ & $\mathbf{4}$ \\
\hline $\mathbf{0 -}$ & 0 & 0 & 0 & 0 & 0 & 0 & 0 & $\mathbf{7}$ \\
\hline
\end{tabular}

\section{CONCLUSION}

In this study, a system that can accurately detect blood group using image processing techniques is proposed. A study was carried out on the patient dataset collected from the Karapinar State Hospital Laboratory. The data set consists of digital images taken through a camera with a resolution of $12 \mathrm{MP}$. The data set consists of a total of 52 images obtained from previously tested blood samples, and the blood group of these images is already known. In this data set, at least three and at most five images were taken from each type of blood group. These images were processed by image processing methods. First of all, images were converted to gray level and then to binary format. Noisy data were destroyed by morphological processes on the obtained image. After each image was divided into three sections, white pixel density, number of objects and number of edges were determined and these data were analyzed to determine which blood group the image belongs to by the classification technique used. When the results of the application were evaluated, it was observed that the use of 3 different features in blood group determination was an important factor in achieving successful results. While the success rate in the determination of group A blood was high, especially in group B blood determination due to the $\mathrm{Rh}$ factor, increased the error. This is because the parameter values of the number of edges and number of objects used in determining the $\mathrm{Rh}$ factor are close to each other.

\section{REFERENCES}

[1] A. Yamin, F. Imran, U. Akbar, and S. Hassan Tanvir, "Image Processing Based Detection \& Classification of Blood Group Using Color Images", 2017 International Conference of Communication, Computing and Digital Systems (C-CODE), 2017.

[2] D. T. R. Singh, S. Roy, and O. I. Singh, "A New Local Adaptive Thresholding Technique in Binarization," IJCSI International Journal of Computer Science Issues, vol. 8, no. 6, no.2. Nov, 2011. 
[3] A. Dada, D. Beck, G. Schmitz."Automation andData Processing in Blood Banking Using the Ortho AutoVue®Innova System", Transfusion Medicine Hemotherapy, vol. 34, pp. 341-346, Sep. 2007.

[4] B. A. Myhre, D. McRuer., "Human error - a significant cause of transfusion mortality," Transfusion, vol. 40, pp. 879-885, July 2000.

[5] Dr. Derek N., Handbook of Transfusion Medicine, 5th ed., TSO, Norwich, United Kingdom, 2013.

[6] S. Rahman, Md. Atifur Rahman, F. Ashraf Khan, S. Binte Shahjahan and K. Nahar, "Blood Group Detection using Image Processing Techniques," Computer Eng. thesis, Department of Computer Science and Engineering, BRAC University, 24 December 2017.

[7] G. Ravindran, T. Joby, M. Pravin, and P. Pandiyan, "Determination and Classification of Blood Types using Image Processing Techniques," International Journal of Computer Applications, vol. 157, no. 1, pp. 12-16, Jan. 2017.

[8] R.A. Rathod and R.A. Pathan, "Determination and Classification of Human Blood Types using SIFT transform and SVM Classifier," International Journal of Advanced Research in Electrical, Electronics and Instrumentation Engineering, vol 5, Issue 11, Nov. 2016.

[9] A. Dhande, P. Bhoir and V. Gade, "Identifying the blood group using Image Processing," International Research Journal of Engineering and Technology, vol 05, Issue 03, Mar. 2018.

[10] A. Ferraz, "Automatic system for determining of blood type using imageprocessing techniques," Sensors \& Actuators, vol 172, Issue 1, Dec. 2011.

[11] Akshaya P. Sahastrabuddhe, Dr. Sayyad D. Ajij, "Blood group Detection and RBC, WBC Counting: An Image Processing Approach," International Journal Of Engineering And Computer Science, ISSN: 23197242, vol. 5, Issue 10, Oct. 2016. 